\title{
浅谈乡村学校利用“四个一”提升学生综合素养的策略
}

\author{
吕清点 \\ 六盘水市钟山区大湾镇中心校 \\ D O I:10.32629/jief.v2i1.446
}

[摘 要] 学校提倡“四个一” 行动, 每周为家长洗一次脚, 每周为家长读一篇好文章, 每周做一次家务事, 每周在学校尽一次义务。目前快 节奏的生活导致的很多家庭教育的失调, 需要传统以“孝” 文化引领学生的思想, 这是一项可操作性强、影响广泛、在小学普及德育教育工 作一项意义深远的工程。大湾中心校以此为突破口，结合学校开展的德育课题，使学生学会尊重父母，孝敬家人，养成勤劳自立的良好习惯。 [关键词］四个一；提升；综合素养

作为教师的我们, 也要适应社会发展去进行相关的教育教学活动。 而在教学的过程中, 通过课题研究活动来提升学生全面的素养也是教师的 任务之一。

\section{1 学校开展“四个一”课题研究的意义}

《多村学校开展 “四个一”工程研究与实践》的研究课题是整个中心 校全体师生执行学校开展 “四个一” 活动以来的成果的汇总, 是学校校园 文化的重心, 是打造校同形象, 树立校园品牌的最佳模式。对推动影响学 校今后的各项发展都有积极的促进作用, 使学校在当地的影响力得到了极 大的提高, 并且从学生参与课题活动中的一些途径来提升学生的综合素 养。

\section{2 教育学生在家以孝为先, 用实际行动孝敬父母}

在学校利用班会课或课题开展的指导学生进行演讲的活动教育学 生, 让学生认识到是谁赋予他们生命, 抚养他们, 教育他们, 让他们能够 在蓝天下健康成长, 快乐生活, 是父母啊! 在成长的道路上, 是自己的父 母为他们付出了许多。在教学过程中, 运用典型的一些案例教育学生用自 己的实际行动来孝敬自己的亲人。百善孝为先, 自古以来就是中华民族的 传统美德。在漫长的历史长河中, 中华民族在孝敬父母方面曾涌现过不少 令人感动的故事。如《骆驼妈妈的故事》、《黄香温席》等, 利用这些故事 引导启发学生在家里要孝敬父母, 我们可以用一个甜甜的微笑, 一声亲切 的问候, 一杯热茶表达自己的孝心, 帮助父母做家务。乡村学校的孩子, 每周帮助父母做家务都超过一次以上, 学校在部分老师在学校开展课题活 动的引领下, 每周让学生回家给自己的父母洗一次脚, 让学生收集相关的 图片和做事之后的感想, 很多的学生平时在语言上没有对父母关心的话通 过书面的形式的表达出来, 也让学生体会到自己父母的辛苦, 让学生感知 在学校时应该尊师爱友, 努力学习, 不幸负父母的期望, 用自己在学习上 的进步作为表达孝心的最好礼物, 同时感恩父母也是自身综合素养慢慢提 升的一种体现, 常言道只有对自己父母好的人以后才会在工作中真心对待 自己的同事、对自己的朋友、自己的事业。

\section{3让学生利用每周读一篇好文章提升自己的综合素养}

“读一本好书, 就是与高尚的人谈话”。高尚的人有许多值得我们领 略的思想和品格, 我们如果有一本好书, 而且认真去领略他的思想, 就向 是在了解高尚人的思想, 学习高尚人的品格, 所以读好书和高尚的人谈话 是差不多的, 目的都是更加完善自我, 我们每一个学生要在书籍的世界里, 有自己的生活, 把读书, 应视为自己的乐趣 ${ }^{[1]}$ 。

读书就像吃饭一样, 学生小时候吃的饭菜学生并不一定都能够记得, 但是所吃的那些饭菜, 它们慢慢的成了你身体的一部分。读书, 特别是读 一本好书或者一篇好的文章, 就像吃饭一样, 慢慢丰富学生的知识, 开阔 学生的眼界, 书中的知识慢慢融进学生的骨血之中, 让你所教的学生慢慢 地变得更有气质和修养。在整个中心校, 我们课题组要求每位学生读一篇 好文章给家长听, 学生选择寓言故事等有教育意义的文章读给家长听后, 学生的表达能力得到锻炼, 并且与父母互相进行交流, 增进学生与自己父
母的交流, 学生自己能将知识融会到自身, 如现在学校课题组老师带领的 五 (1) 班, 六 (2) 班的好多学生都爱看《伊索寓言》这本书, 将书中这 些知识积累于身在以后展现出来的是学生一个综合素养的体现,

4 利用义务劳动培养学生的自理能力, 提升自身综合素养。

教育是教育活动的出发点和归宿, 要开展劳动教育就要强调学校义 务劳动, 要通过学校义务劳动使学生形成一种自觉劳动的行为方式, 力戒 贪图享受, 好逸恶劳的不良倾向, 体会劳动的艰苦, 也品尝劳动的快乐。 并在义务劳动过程中逐渐培养学生团结协作、艰苦创业, 以社会利益为先 的精神和勇敢顽强的意志, 使学生感受到: 美好的环境是靠大家共同努力 创造出来的, 懂得社会的利益远大于个人的得失, 懂得珍惜劳动成果, 尊 重自己与他人的劳动 ${ }^{[2]}$ 。

现在 “学生综合素质测评” 的评估有智力和非智力评估, 已经完全 代替原来 “纯学科分数” 的评估手段, 在学校课题研究这方面, 我们建立 参加学校义务劳动的相关规定和制度, 要求每个班级建立一档, 定期记载, 要求每个班级带领学生每周做一次义务劳动, 使劳动教育与文化教育互相 结合, 定期向学校有关方面反馈。在学校的教育中, 在保证适量的情况下 学生参加劳动是必须的, 对积极带领学生参加义务劳动的班级给予表彰, 不及格者给与指正, 使义务劳动的评价过程和结果落实到每个学生身上。 学校义务劳动是实践劳动知识, 体验劳动生活, 培养劳动情感、态度、形 成劳动价值观, 进一步提高对劳动的认知的最佳途径, 是学习劳动技能, 初步养成自立自理能力的有效途径。同时让学生每周一次的义务劳动, 让 学生认识到劳动的光荣, 自学维护学校的卫生, 学校的实践活动已经成为 提升学生综合素养的一种重要途径, 同时也是学生自身综合素养的一个提 升的一个平台。

\section{5 结束语}

素质教育就是中国的现代教育, 学校教育除了要让学生学习科学文 化知识外, 还要让学生在各方面全面发展, 提高综合素质, 以适应时代需 求 ${ }^{[3]}$ 。本文专注学生综合素养的提升尝试提出学校的一些做法, 把探索乡 村学校利用 “四个一” 提升学生综合素养的实践策略当作一项重要课题进 行研究, 已经取得一定的实效性。

\section{[参考文献]}

[1] 解文平. 实施国学经典教育, 提升学生综合素养 [N]. 语言文字 报,2020-02-14(003).

[2] 孙金坤,浅议提高学生综合素质能力的方法 [J].科教导刊 : 电子 版,2016(1):23-23.

[3]王丹丹.乡村学校语文整本书阅读教学的实践应用 [J]. 读与写(教 育教学刊),2020,17(02):52.

作者简介: 吕清睿 (1974), 女, 白族, 贵州钟山人, 大学专科, 高级教师 (小), 长期从事小学教育教学方面的研究, 要让学生学习 科学文化知识外, 还要让学生在各方面全面发展, 提高综合素质, 以 适应时代需求。 